\title{
SOCIAL AND SPATIAL CONTINUITIES AND DIFFERENTIATIONS AMONG PORTUGUESE CIGANOS: REGIONAL PROFILES
}

\section{MARIA MANUELA MENDES, ${ }^{1}$ OLGA MAGANO² AND PEDRO CANDEIAS 3}

\begin{abstract}
The coexistence of people and societies marked by ethnic, social, cultural, religious and linguistic diversity is a subject that still generates controversies in contemporary societies. The "Ciganos' situation" is an unavoidable issue that crosses the boundaries of different European countries, which leads to controversy and ambivalence in the so-called multicultural and/or intercultural societies characterised by the principle of universalism. In Portugal, despite the social and economic transformations that have occurred, the problems of exclusion and poverty among Ciganos persist. They are still considered the poorest ethnic group, with the worst housing conditions, lest schooling and the main target of racism and discrimination. The Portuguese Ciganos are not a homogeneous community. The diversity and plurality are not always easy to grasp by the glare generated by the adoption of interpretive perspectives that are reductively linear and deterministic of the Portuguese Ciganos. For the purpose of outlining a national picture of Portuguese Ciganos, a national study was developed that combines both qualitative and quantitative methodological approaches. The central goal of this article is to present the main results obtained through a questionnaire survey carried out to Ciganos persons and to discuss the social and spatial continuities and differentiations among Ciganos in Portugal.
\end{abstract}

Keywords: Ciganos, Roma, social continuities, social differentiations, Portugal

\section{Introduction}

The "Ciganos' situation" crosses the boundaries of different European countries, which leads to controversy and ambivalence in the so-called multicultural and/or intercultural societies and which are characterised by the principle of

${ }^{1}$ Faculty of Architecture, University of Lisbon, Portugal; Instituto Universitário de Lisboa (ISCTE-IUL), CIES-IUL, Lisboa, Portugal, e-mail: mamendesster@gmail.com.

2 Portuguese Open University (UAb), e-mail: olga.magano@uab.pt.

3 ICS, Institute of Social Sciences of the University of Lisbon and SOCIUS, Research Centre in Economic and Organizational Sociology, Lisbon, Portugal, e-mail: pedromecandeias@gmail.com. 
universalism in social policies. The Portuguese Ciganos [corresponding to the English "Gypsies"] do not self-identify with the word "Roma" or "Roms", but with the term "Ciganos", with the exception of some mediators, association leaders and people with average and higher education, activists and members of Roma movement, who know this designation. For this reason, we chose to use in this text the term "Ciganos", when we refer to the Portuguese Roma4. Despite the social and economic transformations that have occurred in the Portuguese population in general and in the Ciganos population in particular since 1974, with the turn towards the implementation of the democratic system, the problems of exclusion and poverty among Ciganos persist. They are the poorest ethnic group, with the worst housing conditions, least schooling and the main target of racism and discrimination. According to the European Union Agency for Fundamental Rights Agency (FRA, 2012) and the World Bank (2014), Roma individuals and families are severely affected by social and economic vulnerability, which results from a complex set of factors that are all linked together. The empirical evidence of a research performed by the FRA (2012) in 11 Member States shows that $80 \%$ of Roma respondents were at risk of poverty 5 . The highest levels belonged to Portugal (almost 100\%), Italy and France. The results show the existence of strong disparities between the Roma and the non-Roma: on average, less than one in three Roma individuals has a paid job and one in three non-Roma respondents living among or in the proximity of impoverished Roma settlements is unemployed (FRA, 2012). Specifically in France, Italy and Portugal, only about one in ten individuals aged 20 to 64 years old holds a paid job. In fact, Ciganos are in a disadvantageous position when applying for a job, not only due to the lack of educational and professional credentials, but also because sometimes they are discriminated against (FRA, 2012). This project was probably the most extensive research that has involved the largest number of participants: 11 countries (Bulgaria, Czech Republic, France, Greece, Italy, Hungary, Poland, Portugal, Romania, Slovakia, and Spain), 22,203 households and data from 84,207 household members. From a methodological point of view, the research was relatively innovative, establishing a comparison with the non-Roma population living near the Roma. Thus, these 22,203 responses do not concern only the Roma people but also the non-Roma who reside in areas of high concentration of Roma. Methodologically,

\footnotetext{
${ }^{4}$ Ciganos speak Caló or Romanon/Romanó, which basically encompasses a range of regional dialects of Spanish with numerous Romani loan words.

5 The at-risk-of-poverty rate is the share of people with an equivalised disposable income (after social transfer) below the at-risk-of-poverty threshold, which is set at $60 \%$ of the national median equivalised disposable income after social transfers. In http://ec.europa.eu/eurostat/statistics-explained/index.php/Glossary:At-risk-of-poverty_rate [Last accessed: 22.05.2016].
} 
this strategy can be especially useful in countries where there is a high stigma associated with the Roma self-identification. These are individuals and families characterised by an unavoidable cycle in which there is a self-perpetuation of unequal opportunities, discriminatory practices and hard to achieve aspirations.

The national bibliography reveals several changes and transformations that marked the living conditions, socio-economic and cultural practices of Portuguese Ciganos (Mendes, 2007; Lopes, 2008; Nicolau, 2010; Magano, 2010; Bastos, 2012; Brazzabeni, 2012). The studies on Ciganos before the Portuguese Revolution (25th April, 1974) focused on the search of ethnological features and involved especially residents in rural areas at the end of the $19^{\text {th }}$ century (Coelho, 1995 [1892]) or in the 1970s (Nunes, 1996). The Revolution, "in which the restoration of democratic system resulted in the stabilization of citizenship rights, enshrining civil and political rights and broadening and deepening social rights" (Pereirinha e Carolo, 2009: 5) has led to the implementation of the principle of universalism in public policies. This guiding principle reinforced the responsibility of the State and society in general to promote the improvement of living conditions for all citizens. Nevertheless, recent data indicate disparities among Ciganos and non-Ciganos in important areas, such as education, employment, health and housing (Mendes et al., 2014). In order to ensure the existence of effective policies for the integration of the Roma in the EU, in 2011 the Commission proposed the issuing of national strategies for integration or, if these already exist, their adaptation to achieve EU objectives related to Roma integration (European Parliament, 2011). These objectives are based on four important areas, which are also the key axes that guide the National Strategy: access to education, employment, healthcare and housing (ACIDI, 2013).

There is no statistical information on Ciganos at national level, since the Portuguese Constitution sets several restrictions on ethnic statistics and any other element allowing the ethnic identification of citizens. The recently published national study on Ciganos communities (Mendes et al., 2014), which was developed in the framework of the Portuguese National Strategy, seeks to solve this shortcoming in the national scientific arena. The completion of this study enabled the elaboration of a social, cultural and economic picture related to the "Ciganos communities". This designation is used by the High Commissioner for Migration and it conferred the title of the study funded by this institution. The authors understand that, in general, it is not possible to talk about "Ciganos communities" in the sociological and anthropological sense. The use of this designation tends to homogenise and reify interpretative perspectives about Ciganos persons. In fact, the fieldwork with Ciganos persons residing in the same space reveals various different forms of lifestyles, cultural traits and multiple identity statements. 
Our survey from 2014 allows us to portray general aspects about the living conditions of the Portuguese Ciganos, and also to depict the intra-heterogeneity that marks Portuguese Ciganos, reflected in social and geographical differentiations and some continuities.

\section{Theoretical context and the relevance of the study}

Although since the 1990s there has been an increase in the number and quality of studies related to Ciganos in Portugal, qualitative studies of local neighbourhoods and well delimited geographical areas have prevailed (Sousa, 2010; Mendes, 1997 and 2007; Nicolau, 2010; Magano, 2000 and 2010; Casa-Nova, 2009; Castro, 2004; Lopes, 2008, Blanes, 2006; Brinca, 2009, Bastos, 2007 and 2012; Brazzabeni, 2012; Silva, 2015). There is a gap in terms of longitudinal studies and a lack of statistical data on characteristics and lifestyles of the Portuguese Ciganos because of the difficulty in gathering data due to constitutional restrictions, but also because of the difficulty in delimiting the sampling frame (the population) and the selected sample as such, for example, it is difficult to delimit a Cigano individual (Messing, 2014). The criteria more frequently used are the self-identification and hetero-identification. In the national context, several studies have tried to demystify the essence that normally involves the excessive homogenisation of the Ciganos concept (Mendes, 2007; Magano, 2014; Mendes et al., 2014), namely concerning the social and cultural characteristics and lifestyles that vary according to residence area and type of housing, family history, social interaction with the surrounding society and social status.

"The Roma" concept is a complex and multidimensional one, assigned to a vast diversity of groups and sub-groups broadly defined as Roma (Ivanov, Keller, and Till-Tentschert, 2015: 2), with the objective of using a non-pejorative designation that may refer to all Roma. However, this general convention is relatively recent and not always accepted passively by all those who consider themselves as being Ciganos, Manoush, Gitanos etc. this designation is vulgarized in EU countries (Simhandl, 2009). Roma identity is a multidimensional concept, a complex construct that can be associated with numerous different elements, constructing complex and dynamic combinations and not a static frame. It gains different connotations in different historical contexts. The same applies also to the way Roma present themselves to others, making Roma identity quite situational and reflexive, defined vis-à-vis the non-Roma.

Referring to the situation that characterises Roma in Central and Eastern Europe, Marushiakova and Popov (2001: 33-34) draw attention to the importance of considering the imprecise and fluctuating data and the non-existence of a model to triangulate the data. So, the best solution is to combine the data from 
different surveys and censuses with personal observations, and subject them to critical analysis. However, the results of this approach are only approximate. Another problem is how to establish who the "genuine" Roma are and how to distinguish the Roma identity. Sometimes some of these people do not want to be recognized and do not wish to declare their ethnic identity for the fear of repressions or because they want to be socially invisible, still others often cannot understand the questionnaires. ${ }^{6}$

Thus, the differences among Roma and the territorial inequalities associated with Roma population are addressed in the international academic literature. In the research project "Poverty and Ethnicity in Central and Southern Europe: 1999-2000" coordinated by Iván Szelényi a questionnaire survey was carried out to the Roma from six countries (Bulgaria, Hungary, Poland, Romania, Russia, Slovakia) and it was concluded that living in the capital was negatively related to poverty in Hungary, Romania and Russia. On the other hand, living in rural areas was positively related to poverty in Poland, Romania and Russia (Czismady, 2003). Likewise, the results of the survey regarding the Roma conducted by the United Nations in Bulgaria, Czech Republic, Hungary, Romania and Slovakia indicated that the lack of food was higher in the rural areas (UNDP, 2003). These results are not only obtained in large international researches. In the study on unemployment of Roma in Hungary (Kertesi and Kézdi, 2011), it was established that this group was over-represented in certain regions of the country, with a greater proportion living in villages and rural areas, especially in villages classified as distant, with few connections to economically important cities and characterised by high unemployment. Finally, it should be noted that, in the study on church attendance of Roma in Romania (Rughiniş, 2011), living in non-urban areas was considered a significant predictor to the frequency of attending religious worship gatherings and ceremonies.

\section{Methodology}

The national study carried out in Portugal was funded by the High Commissioner for Migration and included a variety of methodologies: interviews to experts, on-line surveys to local authorities, face-to-face surveys to Ciganos persons and validation of profiles obtained by the Delphi method. The objective was to report the complexity of the living conditions of Ciganos in Portugal by crossing data of several sources and perspectives of different social actors. In this article, we focus on presenting the questionnaire survey carried out face-to-face to

\footnotetext{
${ }^{6}$ Marushiakova and Popov say "that the official statistical censuses reflect about one-third of the real number of Gypsies in each country" (Marushiakova and Popov, 2001: 34).
} 
Ciganos individuals and families living in mainland Portugal. Taking into account the difficult access to this population and supposing that the majority of the Ciganos population lives in groups (clustered), the door-to-door surveys were not viable since they would have high costs and the results would be restricted to a small sample and of questionable quality (Bjerkan and Huitfeldt, 2004: 26-27).

Thus, in this study and in the implementation of the questionnaire survey to Ciganos we used a procedure inspired in the adaptive cluster sampling (Thompson, 1997: 294), a technique developed in order to query population of difficult access. Specifically, the procedure was as follows: in a first phase some territorial areas were randomly selected to be inquired (clusters). In a second moment, we tried to deepen the fieldwork in those areas where more individuals belonging to the intended target group were found; the areas where few individuals were found were left out. The areas which we had reliable information provided by the mainland municipalities and other sources that large number of Ciganos were living there had been included. The initial points of gathering information were diversified and while choosing them we took into consideration the information from interviews to socio-institutional agents and from surveys performed to local authorities, whose response rate was $54 \%$, as well as previous studies (SOS Racism, 2001; Castro, 2004). It is known that Ciganos are distributed relatively dispersed throughout the country, it's possible, however, to highlight some areas of greater agglomeration, such as the municipalities of the two metropolitan areas (in AM Lisbon, 30.0\% and AM Porto, $23.3 \%$ ) and the Alentejo region (20,0\%). The largest geographic concentrations occur in the districts of Lisbon, Setúbal and Porto, appearing after secondary areas of concentration some municipalities of the Alentejo, Algarve, from the northeastern and Beira Baixa. In spite of the predefined survey areas, according to the largest cores of geographical concentration of Ciganos population: Trás-osMontes e Minho, Porto metropolitan area and Tâmega, Centro e Beira Interior, Lisbon metropolitan area and Setubal region, Alentejo (Alto, Baixo, Litoral), Centro and Algarve, the objective was to diversify the analysed areas (urban, rural and peri-urban profiles).

Among the main criteria we considered in order to obtain an adequate sampling of Portuguese Ciganos, it should be noted that: the sample should be representative of Ciganos (sociological and not statistical); it should have the sufficient dimension to perform solid analyses of the different subgroups within that population; and it should enable the comparison between the Ciganos and non-Ciganos (Bjerkan and Huitfeldt, 2004: 26). The sample encompassed a certain internal diversity through the formation of indicative quotas, taking into account sex, age, and habitat (rural/urban), social status, schooling and residence in areas of high/low concentration of Ciganos, which corresponds to different profiles of Ciganos in Portugal. Among Ciganos there is a diversity of 
situations and social positions, and in Portugal little is known about interclass differences between Ciganos elite, the middle classes and the working class (Gamella, 2013). In addition, there are Ciganos whose families have always been integrated and benefit from greater acceptance either due to their high socioeconomic status, or due to an upward social mobility, often based on a distinctive pathway of academic and vocational qualifications (Magano, 2010; Sousa, 2010). Although, most likely, there is a tendency to survey Ciganos residing in areas of higher concentration of coethnics. An effort was made to also inquire the segment of higher status Ciganos (groups that had been identified in previous studies) and to include as well residents from areas with high concentration of non-Ciganos. Despite this effort, how much of these groups are represented in the sample (as well as in the population the sample was extracted from) remains unknown. As regards citizenship and place of birth, the target population was Portuguese Ciganos, who represented 99\% of the respondents. The remaining less than one percent of non-Portuguese Ciganos (largely born in Spain and with Spanish citizenship) were surveyed because they were culturally related to the Portuguese Ciganos and lived in the same habitats.

It is impossible to quantify/estimate the Roma population, even in countries where ethnicity is declared in the general census of the population, since it is not viable to accurately calculate the error associated with these estimations/samplings. It is recommended in the literature to combine the data of questionnaire surveys with qualitative information gathered from the interviews to experts (Rughiniş, 2010: 354).

One of the methodological problems underlying the survey to Ciganos refers to the means of identification. Therefore, in the survey, we used as key criteria the ethnic self-affiliation, in which the person identifies himself/herself as Cigano (Ladányi and Szelényi, 2001: 81). The question over ethnic self-identification was not a filter question (the interview continued regardless of the response); however, self-identification was registered for each respondent.

The interviews to social-institutional actors (NGOs, public services, churches, mediators, Ciganos representatives) allowed to map and characterise, on a preliminary basis, the survey population, namely if the Ciganos persons live in well-identified communities, in big groups or in small groups or even in isolated areas where mainly non-Ciganos population lives (Rughiniş, 2010: $360-361$ ), the constraints and the opportunities of integration and some of its basic characteristics that were considered while composing the quotas (with correspondence to profiles).

In the face-to-face survey we involved non-Ciganos and Ciganos interviewers alike. However, we were aware that the viability of this type of research project depended on the nature and clarity of its goals/purposes, but especially on the involvement of the members of the minority group in the 
preparation and implementation of the survey (Bjerkan and Huitfeldt, 2004: 8). One of the problems in this type of studies is the distrust of Ciganos to participate in questionnaire surveys. We tried to guarantee the cooperation of active (Ciganos and non-Ciganos) organisations/institutions/associations in the surveyed areas and to consolidate the contact network of the research team, which resulted from their previous research experience dating back several years. In the surveys to experts and in the Delphi method it was also possible to reckon on the collaboration of representatives of the Ciganos persons and families.

The survey to Ciganos was addressed to a representative of the household and included a number of questions that allowed us to get to know some basic characteristics of respondent's household (one survey per household); the other questions were addressed to the respondent. Apart from data collected from the respondents, we elaborated ethnographic notes and respondents filled in records, so that it was possible to obtain context information (such as those related to the habitat), which gave us a more enhanced perspective concerning the living conditions of the respondents. We also tried to use indicators similar to the ones provided by official statistics, so that it was possible to establish comparisons with the non-Ciganos population (Milcher and Ivanov, 2004: 11).

The lack of consensus and reliable estimates of the size, composition and distribution of Ciganos in Portugal imposes additional constraints. The National Strategy for the Integration of Roma in Portugal (ACIDI, 2013) estimates between 40 and 60 thousand Ciganos citizens. The sample design was based on data obtained from previous studies (Castro, 2006; Castro, 2007; REAPN, 2009 and IGOT-UL, REHURB, 2013), and also on expert interviews and an on-line survey addressed to local authorities performed earlier within this study. Given the already mentioned limitations of national and international sources and the absence a quantitative consensus on the number of Ciganos in Portugal, in the initial phase the sample size was calculated using Epi Info 7. Taking as a maximum size a population of 60,000 individuals, and attempting at an $80 \%$ confidence and a maximum error of $5 \%$, a sample of 1,500 persons would be required. Our fieldwork managed to exceed this number and we eventually covered 1,599 households.

The survey was elaborated on the basis of available information from qualitative studies on the main characteristics of the living conditions of Ciganos, and it was structured taking into account the following dimensions: i) labour market, ii) accommodation and housing conditions, iii) health and nutrition, iv) education, v) social and political participation, vi) social representations and practices, vii) traditions and identity features. A pre-test was performed in order to validate the questionnaire. 
The survey was carried out between April and July 2014. The interviewer team was composed of more than 100 interviewers, some of them Ciganos themselves. Interviewers took part in a prior training on the implementation of the survey, with detailed explanation of the interview guide. The fieldwork was facilitated due to the cooperation of active (Ciganos and non-Ciganos) organisations/ institutions/ associations in the survey areas and to the contact network of some team members of the research. The questionnaire was answered by people at the minimum age of 16 years (no maximum age was defined), of Portuguese citizenship and only by one person from each household. 1,599 individuals were interviewed from 68 municipalities (out of a total of 278 municipalities in mainland Portugal): 940 women (58.8\%) and 659 men (41.2\%). Foreigner Ciganos without Portuguese citizenship were not considered for this study.

\section{Results: a first national portrait of Ciganos in Portugal}

All counties were covered in the mainland territory: we interviewed 1,599 individuals and collected information about 6,809 persons (members of respondents' households). A brief socio-demographic analysis of households' composition points at a young population with a mean age of 24 years. On average, households were composed of 3 people. According to their educational level, the total population living in the surveyed households is distributed as: i) $15.5 \%$ are illiterate; ii) about $30 \%$ do not have complete the first cycle (4 years), or never attended school; iii) approximately $39 \%$ only completed first cycle and only about $6 \%$ had the 3rd cycle ( 9 years); and iv) only $2.5 \%$ completed secondary education or higher. In general, these data are in line with the available studies in Portugal and suggest that Ciganos have low levels of education and often drop out from compulsory education (Bastos et al., 2007; Mendes, 2007; Nicolau, 2010). The main sources of livelihood are based on family support (33.8\%) and Social Insertion Income (33.5\%).

In the group of 1,599 respondents who provided information about the whole household the average age is 36 years, but half of them were below that age. The average age at marriage (including stable cohabitation) is 18 years, and half of the interviewees married when reaching 18 or before. Only $25 \%$ of the sample married above 19. The overwhelming majority of respondents are descendants of Cigano father and mother (91.7\%). Thus, well-established endogamy practices (Mendes, 2007) can be said to enhance strong intra-group homogeneity. The average number of children is two. These data reflect the tendency of decreasing fertility rates that has been reported in other studies as well (Mendes, 1997 and 2007). With regard to the use of Caló (or Iberian 
Romani, is a variant of the Romani language or dialect) $20 \%$ said they never use it, and $21 \%$ use this language sporadically, while $43 \%$ report speaking Caló every day (Figure 1). As one can see in the Figure 1, there is a polarization between those who seldom if ever use Caló and those speaking it frequently. Future studies may explore the factors underlying this frequent use of Caló. Our fieldwork observations suggest that Caló language is not frequently spoken at home, but rather in external contexts, as a form of communication that allows some privacy in front of the non-Ciganos.

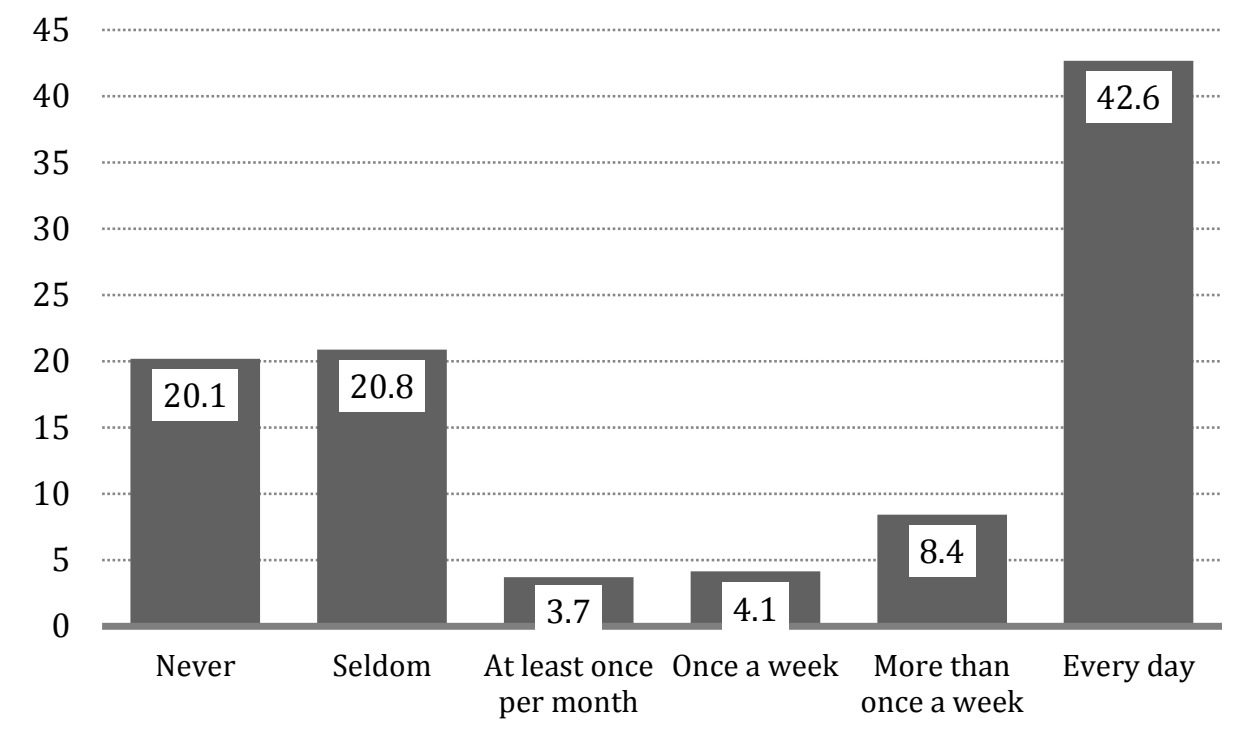

Figure 1. Frequency of the use of Caló (\%)

Data source: National Study on Ciganos Communities, 2014. Authors' calculations.

It is important to highlight only some of the more revealing results on the socio-economic situation of Portuguese Ciganos that clearly point out the fact that the inequalities in the surrounding society are very prominent and persistent. The collected data show sharp differences between the educational levels of Ciganos and non-Ciganos, but also between Ciganos men and women. Thus, about one third of the 1,599 respondents does not exceed primary education or has never attended school, and only $2.8 \%$ have finished secondary or higher education (Mendes et al., 2014). ${ }^{7}$ In the European context, school segregation

\footnotetext{
7 General data about the Portuguese society show that in 2014: 8.9\% couldn't read or write; $19.2 \%$ had finished secondary education and $16.5 \%$ higher education. See http://www.pordata.pt/Portugal, [Last accessed: 6.03.2015].
} 
and other forms of discrimination are also common. We have identified exclusion dynamics affecting Roma who attend school: classification procedures are generated and Roma are moved to special education classes, while their presence in higher education is very small (IRS, 2008).

The aforementioned schooling levels are not equally distributed in the country; it is possible to highlight some regional patterns. In fact, more than half (54\%) of Ciganos from the North region were registered only in the first cycle of primary education (complete or incomplete); in the Central region there are more people that cannot read or write (28\%); and in Alentejo and Algarve the situation is even worse, with 39\% who cannot read or write, while with $38 \%$ were only registered to the first cycle of primary school. When comparing with previous generations, one can state that nowadays there are more in the education system, especially in the first years of schooling, but the majority still cannot exceed the first and second cycles of primary education (Cortesão, 1995; Mendes, 2012; Nicolau, 2010). Since the 1990s, several measures have been implemented in Portugal that helped to increase the schooling levels of the population (for example, Projects of Intercultural Education (PEI), the Educational Territories of Priority Intervention Programme (TEIP), the New Opportunities Programme (PNO), the Choices Programme (Programa "Escolhas"), the PIEF - Support Programme for Education and Training, recently amended to PAQUIEF - Integrated Programme for Education and Training). It is also known that the social integration income (RSI), introduced in 1997 with the designation of minimum income guarantee (RMG), was the policy-measure with the most impact in the increase of schooling levels, in the reduction of high rates of drop-out and school failure. Since then, many Ciganos citizens participated in programs of adult education (back-to-school education and literacy courses), vocational education and other training activities and compulsory school attendance that had an impact in the promotion of schooling levels among Portuguese Ciganos (Gomes, 2013). Despite the improvement of education attainment levels of Portuguese citizens, there still are persistent inequalities between Cigano and non-Cigano people, as well as gender differences that affect Cigano women (Mendes, 2007; Magano, 2010).

Concerning the economic activity, $18 \%$ have paid jobs while $57 \%$ are unemployed or looking for the first job, or have never worked (Mendes et al., 2014). In this respect, it is clear the performance of labour activities was understated (the respondents understand work as a contractual activity, in the formal economy, with regular salary and social rights). This situation contrasts with the results obtained in other qualitative studies performed in the Lisbon and Porto metropolitan areas, where half or more of the interviewed persons were active (Mendes, 1997 and 2007). This empirical evidence can reveal a tendency to reinforce the precarious socio-economic conditions of this population by 
informal, precarious labour. Low-skilled, labour-intensive and monotonous work, along with traditional professional activities, is still common: street trade, agricultural labour, work in cleaning and constructions. This is in line with several studies that have revealed that the main professions/occupations of Ciganos are connected to commercial activities. Many of them continue to work at fairs, markets, in the street or door-to-door (Lopes, 2008 Mendes, 1997 and 2007; Magano, 2010). Their presence in informal sectors (collection and sale of scrap, cleaning activities, Internet sales, bivalve molluscs harvesting, agricultural activities, activities related to the construction sector) and a progressive inclusion in the formal sector (sometimes at the expanse of hiding their ethnic identity) should also be mentioned. The majority of Ciganos continue to take up independent economic activities (employers and self-employed people), while remaining at low levels of professional qualifications. It appears that the structural impact of social policies, such as the social integration income, is not very visible and emergent (Branco, 2003). On the other hand, some Ciganos persons continue to value more independent economic activities, which allow them to manage in a more flexible way their labour and family life (Lopes, 2008). Among those who enter the labour market, it is clear that men are more likely than women to get higher-skilled jobs. This distinction is directly connected to schooling and training levels of both genders (Magano, 2010; Mendes et al., 2014). Ciganos women are struggling with difficulties that are shared by other women in a society that is not inherently equal, and among Ciganos women are still very subordinate and subjugated by cultural tradition or "Gypsy sexism" (Nunes 1996: 93; Casa-Nova, 2009), that assigns higher value to the social role of men and assigns women a subordinate position. Subordination to men remains constant throughout the life cycle of Ciganos women (Magalhães, 2005).

Among Ciganos the duality honour/ shame (Peristiany, 1988) is present in their culturally embedded law and morality, which govern relations between men and women. Ciganos women interviewed in the Lisbon Metropolitan Area (Mendes, 2007) are aware that they live in a situation of institutionalized inequality endemic to the Ciganos, and few women question this situation. Other studies, carried out in the neighbouring Spain, also find that women very rarely put into question their subordinate position, or the values of male authority and female obedience, internalized from an early age as something necessary, as a factor of cohesion and group harmony (Presencia Gitana, 1990).

However, the persistence of inequalities in accessing the labour market does not emerge only from the low schooling levels among Ciganos. In fact, this situation is the consequence of a complex and cumulative discrimination process (Higgins and Brüggeman, 2014) that falls upon Ciganos. In the perspective of Standing (2015) the transformation of social structures produced a new class 
structure at the global level and within each country, and a new category of the "precariat", characterized by chronic uncertainties, irregular employment and lack of financial security. Within the precariat several subclasses could be depicted, such as those who fail to ensure a professional carrier with constant returns, or others who are excluded from the mainstream society, have low market capacity and their work remains precarious, fragile and unstable, associated with randomization, informalisation, deregulation etc. The precariat is characterized by insecurity in access to basic rights and by relative deprivation.

According to our survey, the ratio of people who use the social integration income as their main source of income is higher than the ratio of people who depend mainly on a job. The percentage of people depending on allowances and retirement pensions (3.9\%), temporary subsidies (illness, unemployment and others), social support (3.0\%), or odd jobs (1.8\%) is not significant. On the other hand, it is important to highlight that this population is very young: approximately 34\% are still in the care of relatives (Mendes et al., 2014). We can conclude that the results obtained in relation to the income sources of the interviewees and their families, show that they live in a situation of dispossession that more generally occurs in capitalist societies. Capitalism created dispossessed social groups that do not fall within the working classes in the classical sense or in other possible classes, and there is a sharp distinction between the working class and the poor (Kasmir and Carbonella, 2008).

\section{The regional differentiation of profiles}

The objective of this section is to identify differences in the respondent's profiles according to their region of residence. In order to meet this purpose, the following steps were taken in analytical terms: i) first, a set of relevant variables was selected; ii) afterwards, several principal component analyses (PCA) (Marôco, 2010) with the selected variables were performed until a satisfactory and coherent model was obtained; iii) in the third stage, some counties were aggregated due to the small number of replies. Finally, the factorial scores of PCA were assessed taking into account the average value per county. The analysis of these results was also supplemented by other variables of the questionnaire survey and some official statistics.

A set of variables related to several characteristics of Ciganos in Portugal was selected. These variables refer to their socio-economic status, socio-cultural features, continuity of education, and differentiation by gender and housing 
conditions ${ }^{8}$. With these variables, a principal component analysis was performed; the objective was to reduce the information concerning these variables to new components independent of each other. The Kaiser criterion was used and no kind of rotation was performed. The KMO statistics and the Bartlett test were used as quality indicators of the principal component analysis. The KMO varies between 0 and 1 ; higher values are preferable. The reference value is 0.5 , in this case, the obtained value was 0.665 , which is satisfactory. The second one, the Bartlett test, was significant $(p<0.001)$, which justifies the use of the obtained factors. The factor loadings, as well as the variation percentage explained by each component, are presented in Table 1 . The factor analysis extracted five components: 1) One first component is associated with self-employment, street trading, unemployment and access to social benefits (the last one is negatively related to the first and second ones). 2) The second component aggregates the attitudes towards gender differences. 3) The third component isolates items connected to some housing problems. 4) The next component aggregates indicators associated with formal employment and contributions to Social Security. Finally, the fifth component refers to indicators linked to socio-cultural characteristics, namely church attendance frequency, Ciganos origins and endogamy.

Table 1.

Factorial model

\begin{tabular}{|l|c|c|c|c|c|}
\hline & $\mathbf{1}$ & $\mathbf{2}$ & $\mathbf{3}$ & $\mathbf{4}$ & $\mathbf{5}$ \\
\hline Street trading (dummy) & 0.63 & -0.28 & 0.28 & -0.22 & 0.09 \\
\hline Unemployed (dummy) & -0.59 & 0.26 & -0.21 & -0.16 & 0.02 \\
\hline Self-employed (dummy) & 0.58 & -0.22 & 0.19 & -0.45 & 0.11 \\
\hline Social work beneficiary (dummy) & -0.56 & 0.33 & -0.25 & -0.13 & 0.15 \\
\hline $\begin{array}{l}\text { Boys should attend school longer } \\
\text { than girls (Likert) }\end{array}$ & 0.31 & 0.58 & -0.06 & 0.13 & 0.12 \\
\hline $\begin{array}{l}\text { Boys are more important than } \\
\text { girls (Likert) }\end{array}$ & 0.32 & 0.52 & -0.04 & 0.20 & 0.03 \\
\hline $\begin{array}{l}\text { Women should perform deep } \\
\text { mourning (Likert) }\end{array}$ & 0.21 & 0.52 & -0.12 & 0.14 & 0.05 \\
\hline $\begin{array}{l}\text { Men should take the major } \\
\text { decisions in the family(Likert) }\end{array}$ & 0.47 & 0.49 & -0.03 & 0.15 & -0.06 \\
\hline $\begin{array}{l}\text { Women shouldn't argue with } \\
\text { husband (Likert) }\end{array}$ & 0.38 & 0.48 & -0.12 & 0.00 & -0.17 \\
\hline
\end{tabular}

8 While there are arguments against the use of dummy variables and Likert scales in the same model of factor analysis, there is no consensus in the literature to discourage its use, therefore the analysis was performed. 
SOCIAL AND SPATIAL CONTINUITIES AND DIFFERENTIATIONS AMONG PORTUGUESE CIGANOS...

\begin{tabular}{|l|c|c|c|c|c|}
\hline & $\mathbf{1}$ & $\mathbf{2}$ & $\mathbf{3}$ & $\mathbf{4}$ & $\mathbf{5}$ \\
\hline Home humidity (dummy) & -0.22 & 0.27 & 0.69 & 0.01 & -0.06 \\
\hline House is cold (dummy) & -0.29 & 0.41 & 0.57 & -0.05 & -0.12 \\
\hline Noises at home (dummy) & -0.13 & 0.16 & 0.56 & -0.04 & -0.09 \\
\hline Employee (dummy) & -0.18 & -0.16 & 0.15 & 0.69 & 0.35 \\
\hline $\begin{array}{l}\text { Social Security contributor } \\
\text { (dummy) }\end{array}$ & 0.14 & -0.29 & 0.17 & 0.52 & 0.40 \\
\hline Cigano spouse (dummy) & -0.18 & 0.19 & 0.11 & -0.34 & 0.61 \\
\hline Cigano ancestor (dummy) & -0.01 & 0.17 & 0.01 & -0.31 & 0.54 \\
\hline $\begin{array}{l}\text { Church attendance frequency } \\
\text { (intensity scale) }\end{array}$ & 0.19 & 0.10 & -0.14 & -0.04 & 0.34 \\
\hline Explained variation (\%) & $\mathbf{1 3 . 3}$ & $\mathbf{1 2 . 4}$ & $\mathbf{8 . 6}$ & $\mathbf{8 . 0}$ & $\mathbf{6 . 9}$ \\
\hline
\end{tabular}

Data source: National Study on Ciganos Communities, 2014. Authors' calculations.

During fieldwork we tried to cover all mainland counties; however, some of them had a low response rate, so that it was necessary to aggregate some of the counties with a lower number of answers (the original distribution and the subsequent aggregation can be found in Annex 3).

A little bit over one fifth of respondents (22\%) live in Lisbon, $14 \%$ in Porto and $10 \%$ in Faro. The three counties that are part of the Alentejo region (Beja, Évora and Portalegre) represent $16 \%$ of the sample. The following step consisted in analysing the distribution of factorial scores (obtained through the principal component analysis) by counties.

\section{Precarious work and unemployment}

The first component (Figure 2) associates a higher number of selfemployed people and pedlars and street vendors with Lisbon and Setúbal (LMA or Lisbon metropolitan area), but also with Castelo Branco, Braga and Viana do Castelo (Beiras and Minho). Bragança and Vila Real are characterised by a high number of unemployed people and social service beneficiaries ${ }^{9}$. Alto Douro and Trás-os-Montes have the counties most burdened by interiority (geographical and economic marginality; to be far from the coastal zone) and by peripherization and spatial exclusion processes. The data from Aveiro and

\footnotetext{
${ }_{9}^{9}$ Positive responses were received to this question by all respondents who received some kind of social benefit, whether this where combined with other sources of income or not. It is not possible to know exactly the proportion of respondents who would have as only source of income such benefits.
} 
Coimbra are not so evident but are also relevant. According to the Final Report of the Social Cohesion Benchmark (Instituto de Estudos Sociais e Económicos 2015), the situations with low labour intensity, associated with work regimes that are less regular and structured, are more frequent in the Lisbon and Porto metropolitan areas, in Douro valley (especially north of Viseu and Vila Real) and Algarve. Simultaneously, the regions that are more affected by unemployment are the interior of Alentejo, Setúbal region, and the municipalities of the left shore of Tejo and Algarve. In the north, one can highlight Greater Porto and all north coast.

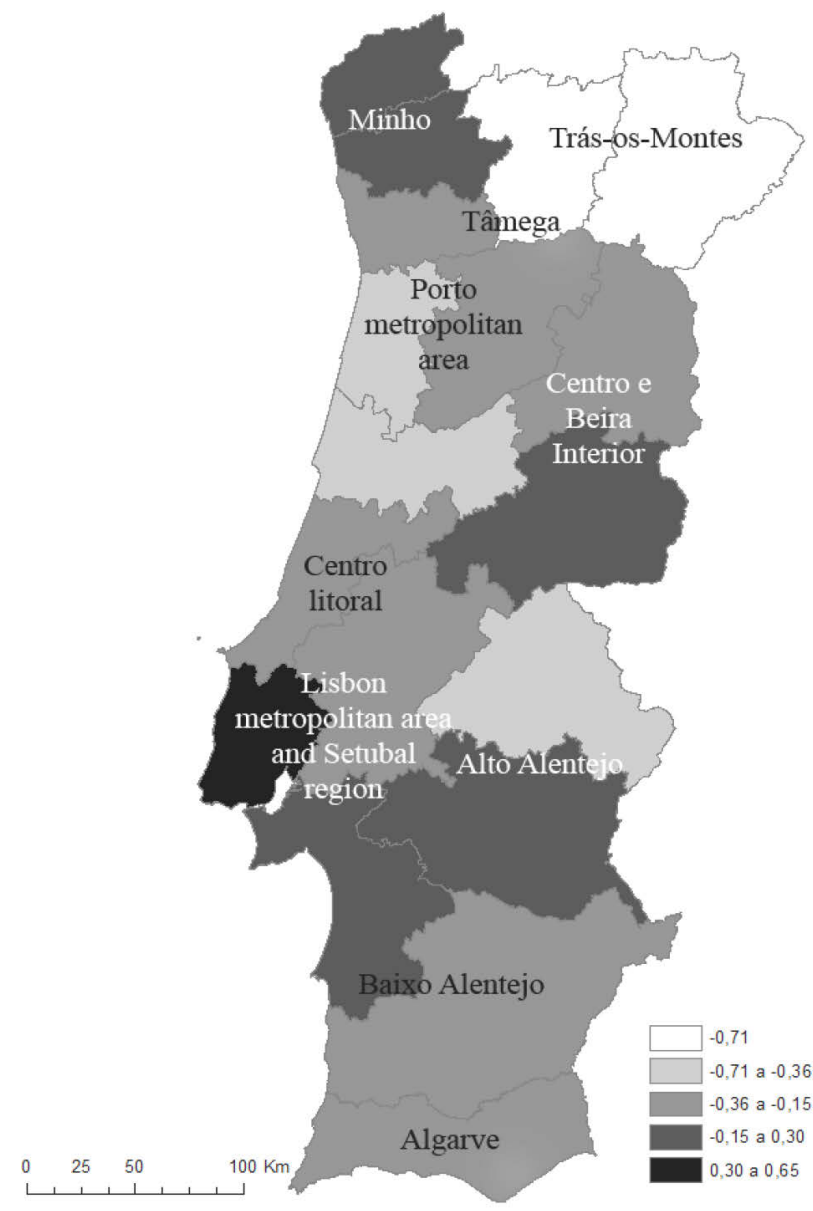

Figure 2. Self-employment and street trading versus unemployment and social services beneficiaries

Data source: National Study on Ciganos Communities, 2014. Authors' calculations. 
This situation is not dissimilar to the one observed by the World Bank for some countries of Central and Eastern Europe (Gatti et al., 2016: 9-10) with the identification of several forms of precarious, unstable, and informal jobs. Limited access to quality education has resulted in important constraints to employability for many Roma and the long periods of unemployment and low wages are often driven by mismatches between the specific skills that employers require - both technical and non-technical - and those usually possessed.

Partially, the results observed in Portugal are also explained by respondents' schooling levels, since the counties where individuals are better educated present the most relevant scores of this component $\left(R^{2}=27 \%\right)^{10}$.

These component scores are also related to the self-evaluation of living conditions ${ }^{11}$. The regions with negative scores of this component, associated with unemployment and strong dependency on social benefits, are also the geographical regions where few people evaluate positively their living conditions. In the opposite direction, the areas where there are higher scores related to informal employment and trading, are also the areas with more people evaluating positively their living conditions $\left(\mathrm{R}^{2}=16 \%\right)$.

The distribution of these scores by county was also related to some official statistics at the territorial level, more specifically the population density and the average monthly income of population in general. Firstly, there is a correlation between this factor and population density (Figure 3). That is, informal employment ${ }^{12}$ presents a greater importance in counties whose population density is higher. The underlying rationale is that informal employment practiced by Ciganos, mostly as pedlars and street vendors, needs a component of active demand that will exist only in some of these regions and among their residents.

Equally relevant for this component is the average monthly income (Figure 4). Here too, the relationship is positive in the sense that in the regions with higher average monthly income there is also a greater share of the informal sector and a lower share of social pension beneficiaries. On the one hand, a contagion effect may exist related to the majority population, as there are greater economic difficulties in regions with less income. A second supplementary explanation is that this informal employment consists of services and sales provided to the majority population that will search for this type of work/services depending on their income. According to IESE (2015), the North and Central part of the country present the worst situations in terms of income levels. In contrast, the best situation is observed in municipalities of the LMA (Lisbon and Setúbal).

10 The percentage of respondents by district that have lower secondary education or higher ( 9 years of schooling or more) was used as schooling indicator.

11 The answer options were: 1 . Lives in poverty. 2. Is poor. 3. Is in an average/normal situation. 4. Lives well. 5 Is rich. The percentage of respondents that chose option 3 or 4 was used as indicator. It should be noted that no respondent chose option 5 .

12 Although the component refers to self-employment and street trading, in this text, this one is also referred as informal employment, since the component 4 has as indicators the paid employment and the contributions to Social Security. 


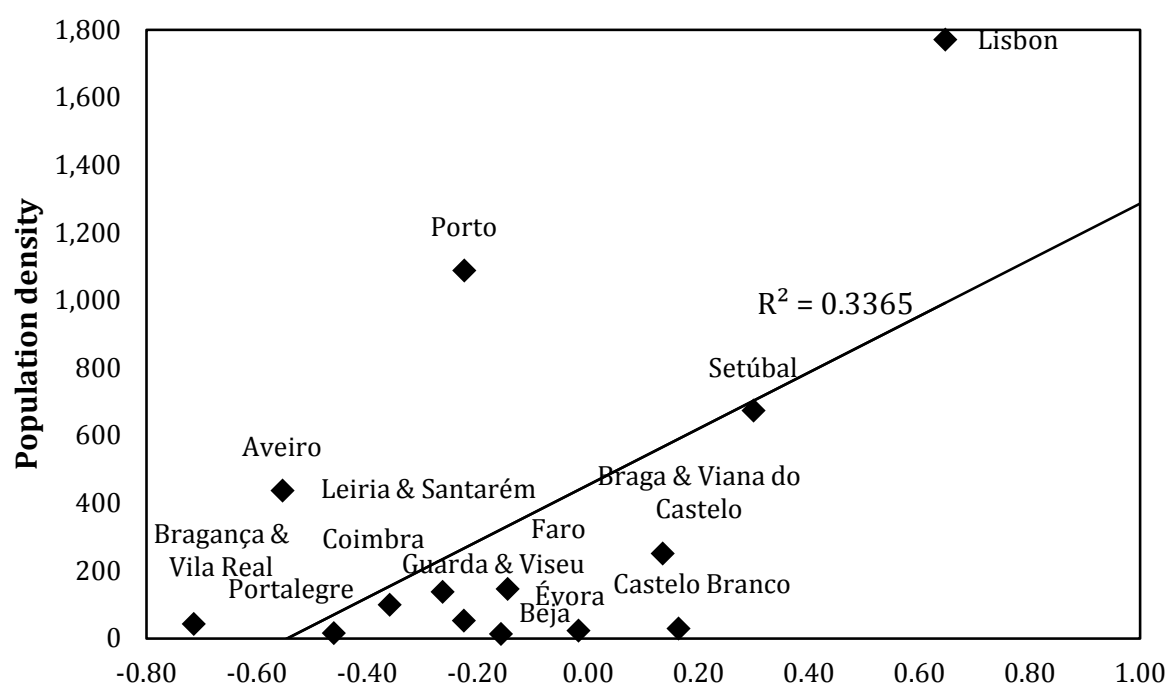

Unemployment and social benefits versus informal employment

Figure 3. Unemployment, informal employment and population density

Data source: National Study on Ciganos Communities, 2014. Authors' calculations.

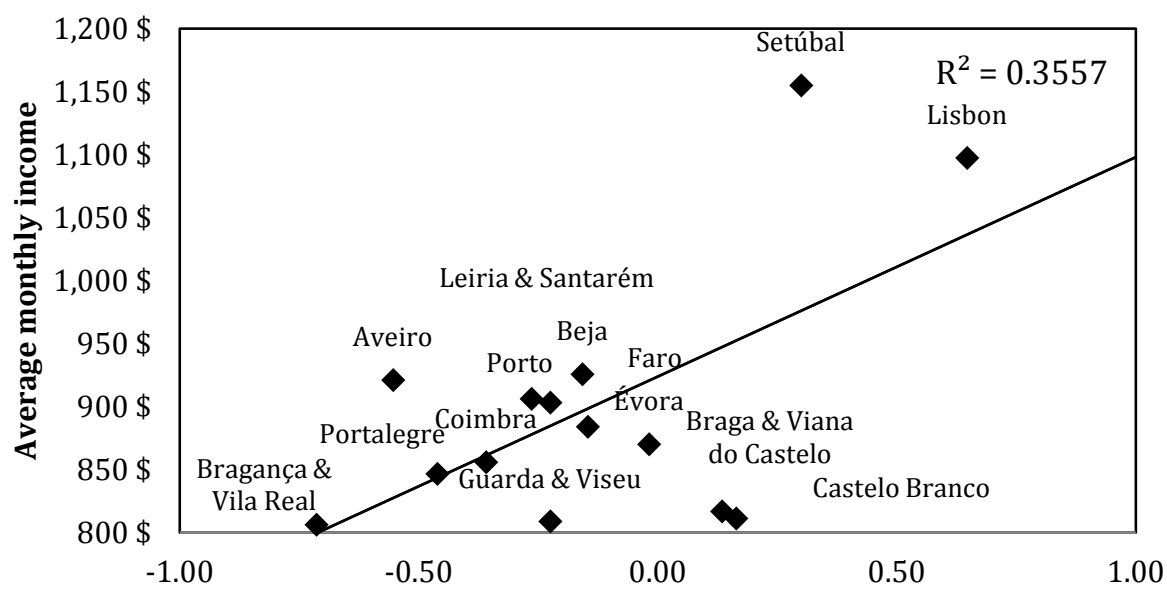

Unemployment and social benefits versus informal employment

Figure 4. Unemployment, informal employment and average monthly income

Data source: National Study on Ciganos Communities, 2014. Authors' calculations. 


\section{Gender attitudes}

The second component refers to some attitudes towards gender differences (Figure 5). The territorial analysis demonstrates residents in municipalities of Beja and Faro are more linked to the preservation of cultural traditions (more "traditional") in terms of gender norms. At the opposite end, more equalitarian attitudes can be observed in Lisbon, Bragança and Vila Real.

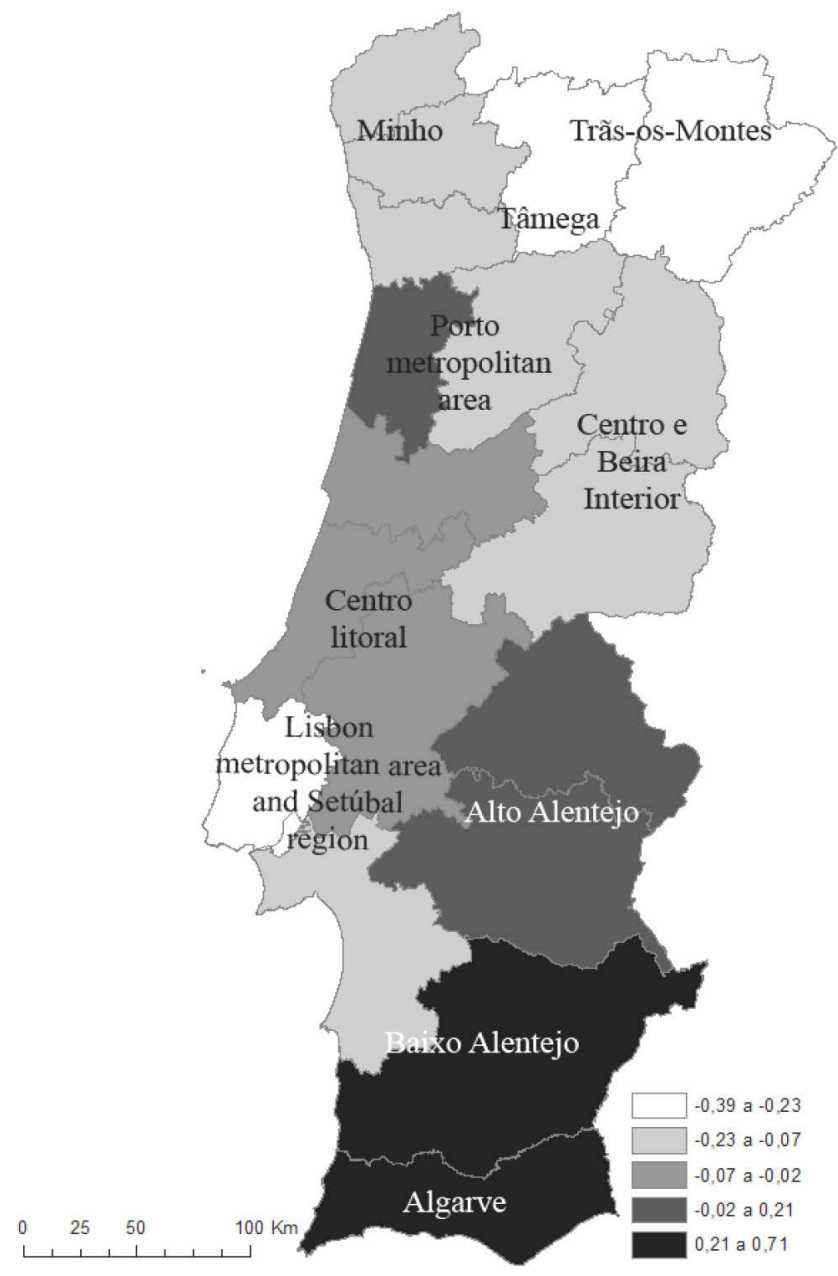

Figure 5. Attitudes towards gender differences

Data source: National Study on Ciganos Communities, 2014. Authors' calculations. 
In search for potential explanations, we looked first at friendly relationships between co-ethnic people. The regions with more respondents declaring to have mostly Ciganos friends ${ }^{13}$ are also the regions where the attitudes towards gender differences are shaped by tradition $\left(\mathrm{R}^{2}=30 \%\right)$. This can mean that little contact of friendship with the exogroup limits the adoption of more open or equalitarian attitudes towards gender relations. Simultaneously, friendly relationships in the endogroup can generate a reproduction of traditional values present in the communities. In accordance with this indicator, the correlation $\left(\mathrm{R}^{2}=13 \%\right)$ with the proportion of respondents whose parents are both Ciganos (in relation to those who have one parent that is non-Ciganos) should be also relevant in the same direction, i.e. the existence of both Ciganos parents might generate a higher closure in the endogroup by reinforcing traditionality through endogamous social closure strategies.

Second, formal education may also play a role, so that we looked at the proportion of individuals with higher schooling levels in the region ${ }^{14}$ in relation to differences in gender attitudes. In this case, the correlation $\left(\mathrm{R}^{2}=24 \%\right)$ is negative. That is, in counties where the schooling level of the respondents is generally higher, the traditionality (the preservation of tradition) towards gender norms is not so pronounced.

In the light of these, we can conclude that contact with educational institutions and the larger society (and with non-Ciganos) can lead to a decrease in sexist attitudes due to the social transformation of Ciganos' cultural norms. If the Ciganos do not live in isolation but as part of society, they will also experience the transformations of social relations within and outside of the family.

\section{Housing problems}

For the third component, some indicators of housing problems are aggregated (Figure 6). They live mostly in houses of the classical type of social rent, with 3 rooms (outside of the kitchen and bathroom), spending on the maintenance between $51 €$ and $200 €$. There are less housing problems in Setúbal, Bragança, Vila Real, Leiria and Santarém. In contrast, the IESE (2015) concludes that the most deficient conditions are registered in rural areas with low population density, in particular, in the majority of the municipalities of Baixo Alentejo and Alentejo Litoral. Alto Alentejo and the North coast are also included. In rural localities with high scores, the characteristics that hold the greatest influence on the score of this indicator are the lack of infrastructures, the overcrowding and the existence of non-classical houses.

13 The respondents had to select one of the following options The majority of your friends are: 1. Ciganos. 2. Ciganos and non-Ciganos. 3. Non-Ciganos.

${ }^{14}$ As an indicator of schooling level, one used the proportion of individuals with lower secondary education or higher. 


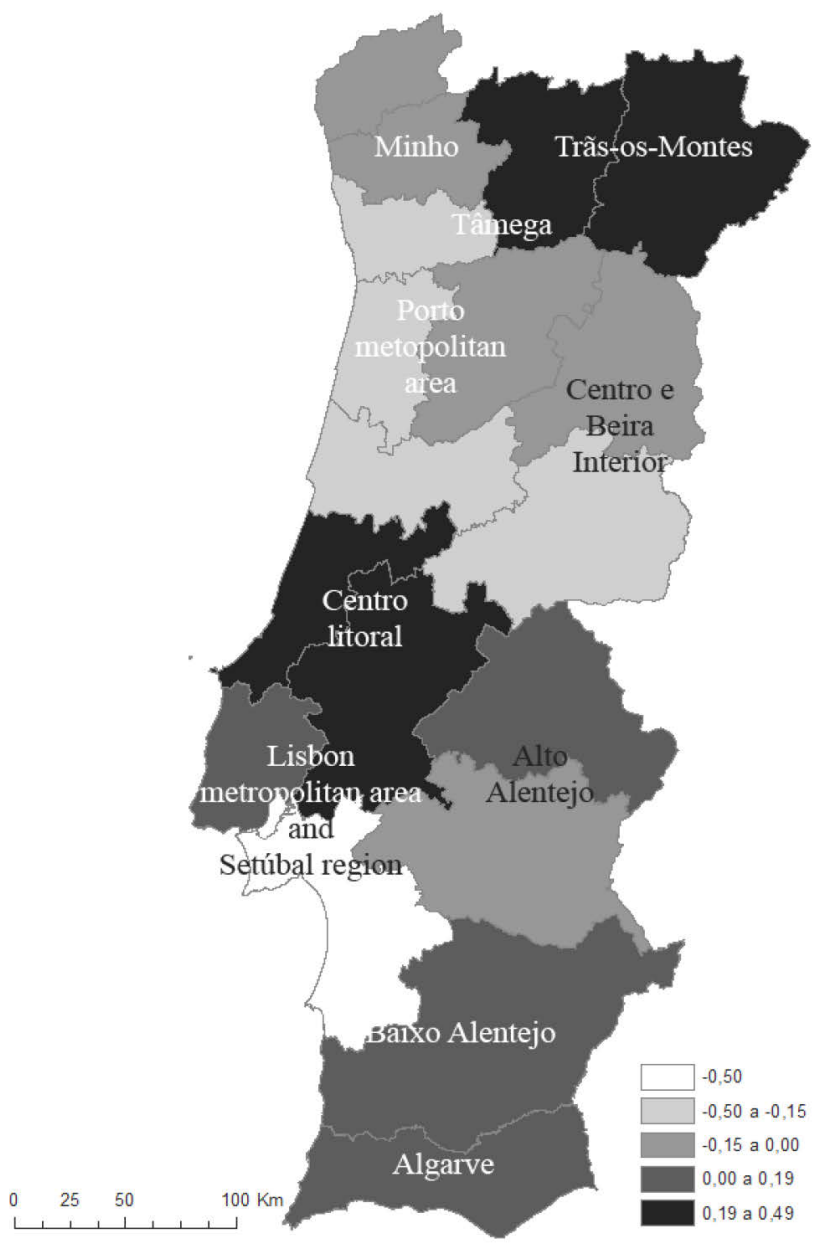

Figure 6. Housing problems

Data source: National Study on Ciganos Communities, 2014. Authors' calculations.

These housing problems are correlated with some factors of aggregate level that result from the questionnaire survey. In particular, higher scores belong to counties with a higher proportion of residents in shanty towns ${ }^{15}$ $\left(\mathrm{R}^{2}=21 \%\right)$ and to counties with longer-term residence ${ }^{16}\left(\mathrm{R}^{2}=12 \%\right)$.

\footnotetext{
15 Questionnaire survey data.

16 The respondents were asked how long they had been living in the same house.
} 


\section{Formal employment}

The fourth component (Figure 7) is composed of two indicators of formal employment (paid employment and contributions to Social Security). The lowest scores are found in Aveiro, while Portalegre is the county with the highest scores for this factor.

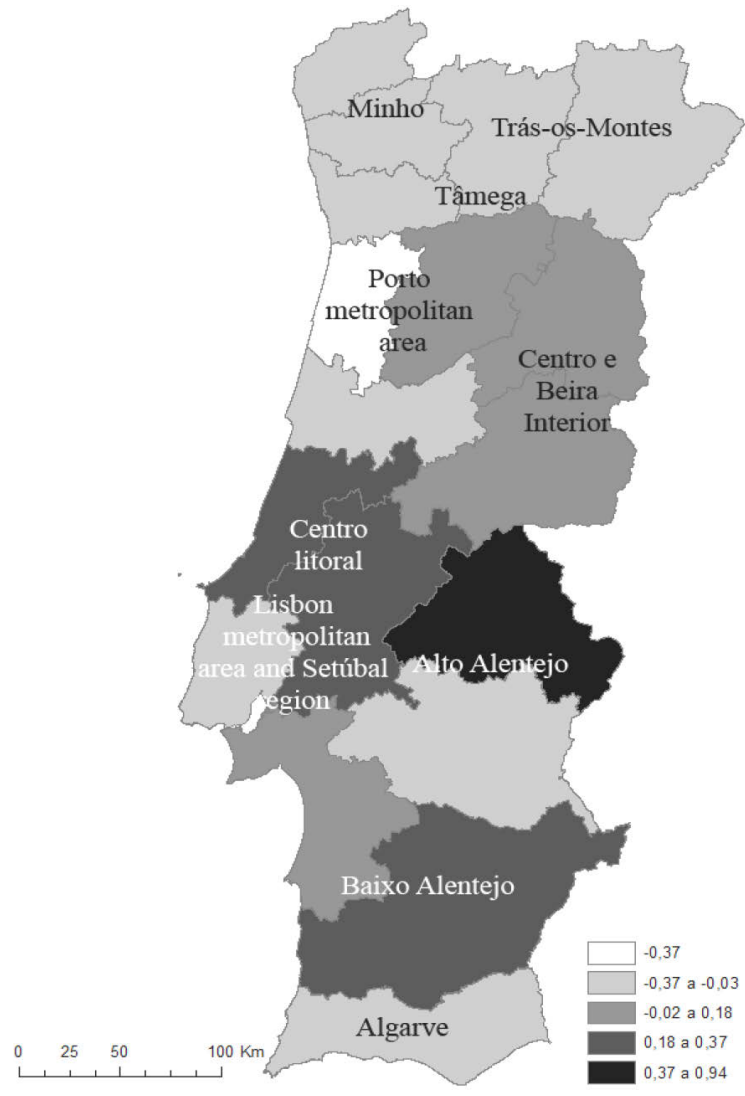

Figure 7. Formal employment

Data source: National Study on Ciganos Communities, 2014. Authors' calculations.

The scores of this component are negatively correlated with a positive life assessment concerning the intergenerational ${ }^{17}$ perspective $(29 \%)$. That is, in the regions with more employees and more contributions to Social Security, the

17 The following question was asked How do you classify your life when comparing it to the life of your parents? The answers were 1 . It is better now. 2 . It is the same as theirs. 3 . It is worse now. The indicator used was the percentage of individuals that selected answer 1 . 
intergenerational assessment is not so positive. In accordance with these results, there is also the correlation of scores concerning social discrimination perception ${ }^{18}$ at county level $\left(\mathrm{R}^{2}=13 \%\right)$. Such results point to the conclusion that paid employment (formal labour contracted by an employer) involves greater contact and stronger interrelation with the majority population, which also leads to a greater exposure to possible situations of discrimination. In turn, this will have impact on individuals' intergenerational assessment of their situation.

When correlating our data with the official statistics, it is relevant the share of the tertiary sector in the total active population (Figure 8). In other words, there seems to be a contagion effect, that is, the majority of the work performed by the interviewed population belongs to the service sector. There is also a relevant share of agricultural labourers and construction workers, but not as high as service providers. This is more relevant in counties where there is an increased labour supply in this sector.

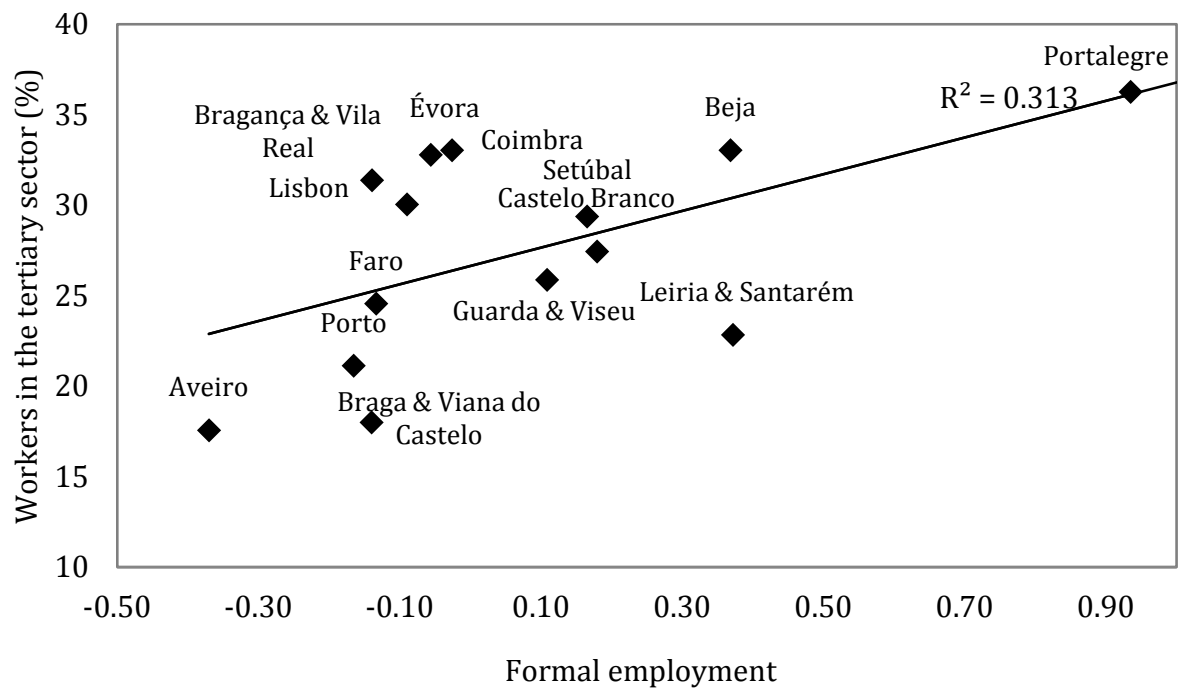

Figure 8. Formal employment and contributions to Social Security and the proportion of workers in the tertiary sector

Data source: National Study on Ciganos Communities, 2014. Authors' calculations.

Regarding Social Insertion Income (RSI) it should be noted that the share of households whose main source of income RSI is $38 \%$, while the remaining most frequent situations are to be in charge of the family (38\%) and live mainly

18 The following question was asked Have you ever felt discriminated because you are a Gypsy? The indicator used was the proportion of individuals that answered affirmatively. 
from work (10\%). This question appeared in the questionnaire as a matter of exclusive answer, thus it is not possible to know from the survey possible conjugations of this benefit with other sources of income. Since RSI is a stable source of income, it is assumed that this has sometimes been indicated as the primary source of income, taking into account the variability of the other sources. Note that in the individual questionnaire $(n=1,599) 915$ respondents claim to have as their main source of income RSI, while $13 \%$ also performed activities as a peddlers / market traders.

\section{Culture and tradition}

The last component relates some indicators regarding socio-cultural aspects (Figure 9). There is a smaller share of people with Ciganos origins and

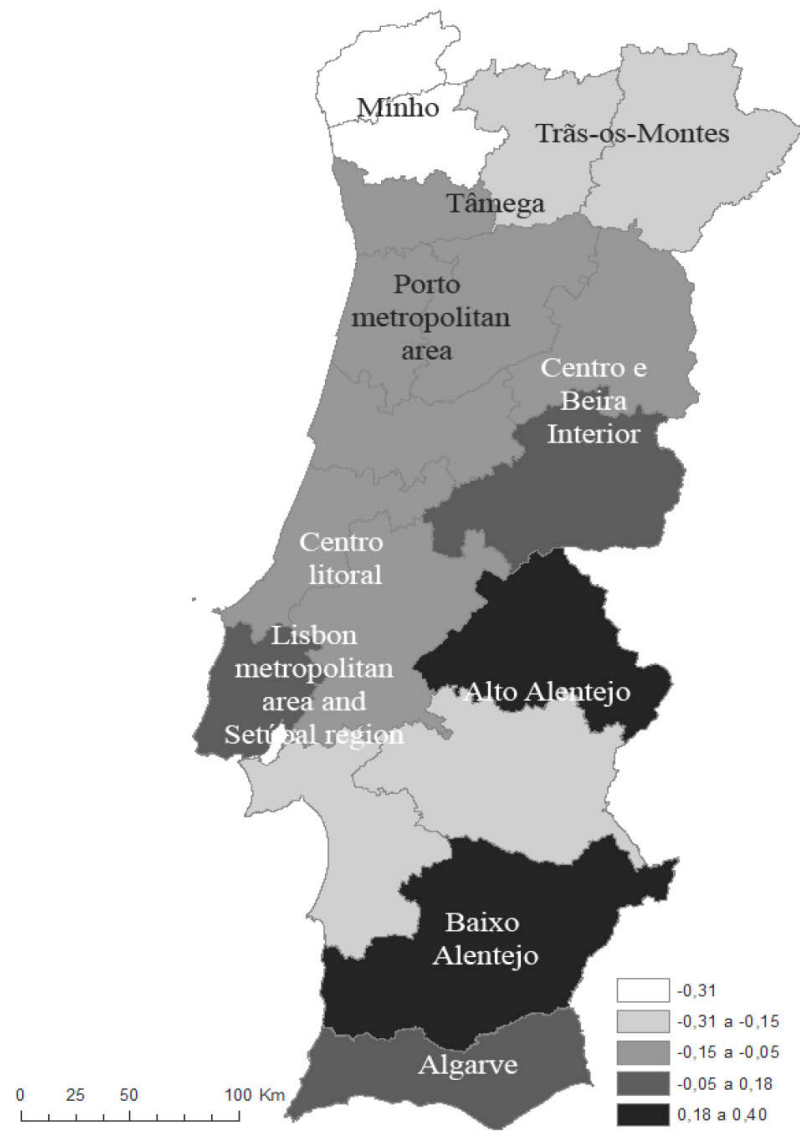

Figure 9. Culture and tradition

Data source: National Study on Ciganos Communities, 2014. Authors' calculations. 
Ciganos spouses and a reduced religious worship frequency in Braga, Viana do Castelo (Minho), Bragança and Vila Real (Trás-os-Montes). On the other hand, Portalegre and Beja (Alentejo) have the highest share in this factor.

For this component, there is a negative correlation with the schooling indicator at the county level $\left(\mathrm{R}^{2}=19 \%\right)$. Nevertheless, without more information, it is not possible to understand which the causal factor is. That is, it might be that higher schooling levels involve lower participation in religious worship and also choice for non-Ciganos spouses. ${ }^{19}$ On the other hand, it might be possible that Ciganos origins, endogamous marital relationship and high participation in religious worship make it difficult to continue formal education in the school system.

\section{Final remarks}

With this analysis it was possible to grasp some regional nuances, mostly related to the singularities that characterise the socio-territorial information about these families, their coexistence with the local societies and the integration policies developed by local authorities and other local institutions and services. We have found some diversity concerning the social profiles, but also territorial patterns, which indicate a certain socio-economic assortment of Ciganos individuals and families.

The results of the questionnaire survey allowed us to get to know the socio-demographic characteristics of households and other dimensions, such as living conditions, employment, health, sociability, religion and social discrimination. It was possible to determine some distinctive characteristics between profiles. These profiles were validated by local experts, and mediators confirmed this diversity among Ciganos (Mendes et al., 2014).

The results obtained from the national study allowed us to conclude that Portuguese Ciganos continue to be largely affected by poverty and social exclusion. Of course, some social policies introduced in Portugal in the last 40 years (since the turn towards democracy) have effectively contributed for the improvement of their living conditions. However, there are significant differences between the living conditions of the Portuguese Ciganos and the Portuguese population in general. The old forms of social inequity expressed in poverty, poor housing conditions, low educational levels, difficult access to the labour market, uncertain incomes and sometimes dependency on social incomes, i.e. "witnessed imprisonment in poverty" (Wacquant, 2014) still exist. Furthermore, the empirical evidence can prove on the one hand a tendency to strengthen the precarious socio-economic conditions of this segment of the population and, on the other hand, it reveals less autonomy in parents' lives.

${ }^{19}$ Clearly, the Ciganos origins are not considered in this hypothesis. 
Finally, we are certain that the data obtained at the regional level is extremely useful for understanding the differences and the contribution of Ciganos to the diversity in plural societies and can inform national and regional policies (Messing, 2014). In fact, the universalism of social policies (equal dignity to all citizens) has not produced the desired results regarding the reduction in levels of poverty, exclusion, discrimination and racism against Ciganos.

\section{REFERENCES}

Alto-Comissário para a Imigração e Diálogo Intercultural (ACIDI) (2013). Estratégia Nacional para a Integração dos Ciganos. Lisbon: Secretary of State of the Deputy Minister and Parliamentary Affairs / ACIDI.

Bastos, J. G. P. (2007). Sintrenses Ciganos: uma Abordagem Estrutural-dinâmica. Sintra: Câmara Municipal de Sintra, Divisão de Saúde e Acção Social.

Bastos, J. P. (ed.) (2012). Portugueses ciganos e ciganofobia em Portugal. Lisboa: Edições Colibri.

Bjerkan, L., and Huitfeldt, A. (2004). Roma Minorities in the Czech and Slovak Republics: Development of a social survey methodology. Oslo: Fafo.

Blanes, Rui L. (2006). Aleluia. Música e identidade num movimento Evangélico cigano na Península Ibérica. Lisboa: Instituto de Ciências Sociais.

Branco, F. (2003). Os ciganos e o RMG: direitos sociais e direito à diferença. Intervenção Social, 27: 119-139.

Brazzabeni, M. (2012). De bairro em bairro: uma família cigana em Vila Real de Santo António entre discriminação burocrática e social e possíveis formas de vida. In José Gabriel Pereira Bastos (ed.): Portugueses Ciganos e Ciganofobia em Portugal. Lisboa: Colibri, pp. 267-278.

Brinca, Ana M. (2009). 'Os ciganos gostam de dar nas vistas, serem falados e gabados'. Exibição e manejo do segredo como estratégia de representação de portugueses ciganos. Ph.D. dissertation in Cultural and Social Antropology. Lisbon: New University of Lisbon.

Casa-Nova, M. J. (2009). Etnografia e produção de conhecimento. Reflexões críticas a partir de uma investigação com ciganos portugueses. Lisbon: ACIDI.

Castro, A. (2004). Ciganos e itinerância - realidades concelhias e formas de hospitalidade. Cidades, Comunidades e Territórios, 9: 55-70.

Castro, A. (2006). Ciganos, Territórios e Itinerância. Análise de um questionário enviado aos postos da Guarda Nacional Republicana. Lisboa: CET/FCT.

Castro, A. (2007). Dos Contextos Locais à Invisibilização Política - Discussão em torno dos ciclos de exclusão habitacional dos ciganos em Portugal. Cidades, Comunidades e Territórios, 15: 63-86.

Castro, A. (2012). Na Luta pelos Bons Lugares: Visibilidade Social e Controvérsias Espaciais. Thesis PhD in Urban Antropology. Lisboa: ISCTE - Instituto Universitário de Lisboa.

Coelho, A. (1995 [1892]). Os Ciganos de Portugal. Um estudo sobre o Calão. Lisboa: Publicações D. Quixote. 
Cortesão, L. (1995). Reflexões críticas sobre a educação de crianças ciganas. In L. Cortesão and F. Pinto (eds). O Povo cigano: cidadãos na sombra - processos explícitos e ocultos de exclusão. Porto: Ed. Afrontamento, pp. 27-36.

Czismady, A. (2003). Poverty and Ethnicity in Six Post-Socialist Countries. Forum, 19: 3-10.

European Parliament (2011). Estratégia da União Europeia para a Inclusão dos Ciganos. European Parliament resolution on the EU strategy for Roma integration (2010/2276, INI). Brussels: European Parliament.

http://www.europarl.europa.eu/document/activities/cont/201101/20110105 ATT11258/20110105ATT11258EN.pdf (Accessed: 20.10.2015).

European Union Agency for Fundamental Rights (FRA) (2012). The situation of Roma in 11 EU Member States Survey results at a glance. Luxembourg: Publications Office of the European Union.

http://fra.europa.eu/sites/default/files/fra_uploads/2099-FRA-2012-Romaat-a-glance)_EN.pdf (Accessed: 20.10.2015).

Gamella, J. (2013). "Sangre y costumbres". Change and permanence in the constitution of a cultural minority: the Gitanos in Spain". In M. Mendes and O. Magano (eds.): Ciganos Portugueses: Olhares plurais e novos desafios numa sociedade em transição. Lisboa: Editora Mundos Sociais, pp. 17-35.

Gatti, R. et al. (2016). Being fair, faring better - Promoting equality of opportunity for marginalized Roma. Washington: World Bank.

http://www-wds.worldbank.org/external/default/WDSContentServer/WDSP/ IB/2016/06/03/090224b08438f623/3_0/Rendered/PDF/Being0fair00fa0or0 marginalized0Roma.pdf (Accessed: 20.10.2015).

Gomes, M. D. C. (2013). Políticas públicas de qualificação de adultos e comunidades ciganas. Movimentos inclusivos. In M. Mendes and O. Magano (eds.), Ciganos Portugueses: Olhares plurais e novos desafios numa sociedade em transição. Lisboa: Editora Mundos Sociais, pp. 81-91.

Higgins, N., and Brüggemann, C. (2014). The Consequences of Cumulative Discrimination: How Special Schooling Influences Employment and Wages of Roma in the Czech Republic. European Educational Research Journal, 13(3): 282-294.

IGOT-UL, REHURB (2013). Base de dados, REHURB - realojamento e regeneração urbana, projeto $P D C / C S-G E O / 108610 / 2008$.

Instituto de Estudos Sociais e Económicos (IESE) (2015). Relatório Final do Referencial de Coesão Social. Lisboa: Instituto da Segurança Social, I.P. e IESE - Instituto de Estudos Sociais e Económicos.

Instituto per la Ricerca Sociale (IRS) (2008). The social situation of the Roma and their improved access to the labour market in the EU.

http://www.europarl.europa.eu/document/activities/cont/201107/20110718 ATT24290/20110718AT T24290EN.pdf (Accessed: 20.10.2015).

Ivanov, A., Keller, S., and Till-Tentschert, U. (2015). Roma Poverty and deprivation: the need for multidimensional ant-poverty measures. University of Oxford. POHI, Working Paper No. 96.

http://www.ophi.org.uk/wp-content/uploads/OPHIWP096.pdf (Accessed: 20.10.2015). 
Kasmir, S. and Carbonella, A. (2008). Dispossession and the anthropology of Labor. Critique of Anthropology. Vol. 28 (1): 5-25.

Kertesi, G., and Kézdi, G. (2011). Roma employment in Hungary after the post-communist transition. Economics of Transition, 19(3): 563-610.

Ladányi, J., and Szelényi, I. (2001). The Social Construction of Roma Ethnicity in Bulgaria, Romania and Hungary during Market Transition. Review of Sociology, 7(2): 79-89.

Lopes, D. S. (2008). Deriva cigana: um estudo etnográfico sobre os ciganos de Lisboa. Lisbon: Institute of Social Sciences / Social Sciences Press.

Magalhães, A. M. (2005). "É assim a vida". Um retrato etnográfico do ciclo de vida cigano. Lisboa: Fundação para a Ciência e a Tecnologia.

Magano, 0. (2010). Tracejar vidas normais. Estudo qualitativo sobre a integração social de indivíduos de origem cigana na sociedade portuguesa. Thesis PhD in Sociology. Lisbon: Open University.

Magano, 0. (2014). Tracejar vidas normais. Estudo qualitativo sobre a integração dos ciganos portugueses. Lisboa: Editora Mundos Sociais.

Marôco, J. (2010). Análise Estatística com o PASW (ex-SPSS). Pero Pinheiro: Report Number.

Marushiakova, E., Popov, V. (2001).Historical and Ethnographic Backgraund. Gypsies, Roma, Sinti. In W. Guy (Ed.), Between Past and Future: the Roma of Central and Eastern Europe. Hatfield: University of Hertfordshire Press, pp. 33-53.

Mendes, M. M. (1997). Etnicidade, grupos étnicos e relações multiculturais, no âmbito de uma Sociologia das Relações Étnicas e Rácicas. Master's dissertation in sociology. Porto: Faculdade de Letras da Universidade do Porto.

Mendes, M. M. (2007). Representações face à discriminação: ciganos e imigrantes russos e ucranianos na área metropolitana de Lisboa. PhD thesis in Social Sciences. Lisbon: University of Lisbon.

Mendes, M. M. (2012). Identidades, Racismo e Discriminação: Ciganos da Área Metropolitana de Lisboa. Lisbon: Caleidoscópio.

Mendes, M. M., Magano, O. and Candeias, P. (2014). Estudo Nacional sobre as comunidades ciganas. Lisbon: High Commission for Migration.

Messing V. (2014). Methodological puzzles of surveying Roma/Gypsy populations. Ethnicities, 14(6): 811-829.

Milcher, S., and Ivanov, A. (2004). The United Nations Development Programme's Vulnerability Projects, Roma and Ethnic Data. Roma Rights Quarterly, 1: 7-13.

Montenegro, M. (2012). Aprendendo a ser cigano hoje: empurrando e puxando fronteiras. $\mathrm{PhD}$ thesis in Education Sciences, Adult Training. Lisbon: University of Lisbon, Education Institute.

Nicolau, Lurdes (2010). Ciganos e não ciganos em Trás-os-Montes: investigação de um impasse inter-étnico. PhD thesis in Anthropology. Vila Real: UTAD, Chaves hub.

Nunes, 0. (1996). O Povo Cigano. Porto: Livraria Apostolado da Imprensa.

Parlamento Europeu (2011). Estratégia da União Europeia para a Inclusão dos Ciganos. Resolução do Parlamento Europeu, (2010/2276 (INI)). Strasbourg: Parlamento Europeu. 
Pereirinha, J. A. e Carolo, D. F. (2009). A construção do estado-providência em Portugal: evolução da despesa social de 1935 a 2003. Lisboa: GHES Gabinete de História Económica e Social, ISEG.

http://pascal.iseg.ulisboa.pt/ ghes/wp/wp362009.pdf (Accessed: 20.10.2015).

Peristiany, J. G. (1988 [1965]). Honra e Vergonha. Valores das sociedades mediterrâneas. Lisboa: Fundação Calouste Gulbenkian.

Presencia Gitana (1990). Mujeres gitanas ante el futuro. Madrid: Presencia Gitana.

REAPN (2009). As Comunidades Ciganas e a Saúde: um primeiro retrato nacional. Porto: REAPN - Rede Europeia Anti-Pobreza.

Rughiniş, C. (2010). The forest behind the bar charts: bridging quantitative and qualitative research on Roma/Țigani in contemporary Romania. Patterns of Prejudice, 44(4): 337-367.

Rughiniș, C. (2011). Quantitative tales of ethnic differentiation: measuring and using Roma/Gypsy ethnicity in statistical analyses. Ethnic and Racial Studies, 34(4): 594-619.

Silva, M. C. (2015). Sina Social Cigana. História, comunidades, representações e instituições. Lisboa: Edições Colibri.

Simhandall, K. (2009). Beyond boundaries? Comparing the construction of the political categories "Gypsies" and "Roma" before and after EU enlargement. In N. Sigona and N. Trehan (eds): Romani Politics in Contemporany Europe. Poverty, ethnic mobilization and the neoliberal order. London: Palgrave Macmillan. pp. 72-93.

SOS Racismo (2001). Satispen ta li Sáude e Liberdade, Ciganos, números, abordagens e realidades. Lisboa: SOS Racismo.

Sousa, Carlos J. (2010). Relações interculturais, dinâmicas sociais e estratégias identitárias de uma família cigana português 1827-1959. PhD thesis in Sociology. Lisboa: Universidade Aberta /DCSG.

Standing, G. (2015). The precariat and class struggle. RCCS Annual Review, 7 (7): 3-16.

Thompson, S. K. (1997). Adaptive sampling in behavioral surveys. In Harrison L. and Hughes, A. (eds.). The Validity of Self-Reported Drug Use: Improving the Accuracy of Survey Estimates. NIDA Research Monograph, 167. Rockville, MD: National Institute of Drug Abuse, pp. 296-319.

United Nations Development Programme (UNDP) (2003). Avoiding the Dependency Trap The Roma Human Development Report. Bratislava: United Nations Development Programme.

United Nations Development Programme (UNDP) (2012). Social economy and roma communities - challenges and opportunities. Bucharest: United Nations Development Programme.

Wacquant, L. (2014). Marginality, ethnicity and penality in the neo-liberal city: an analytic cartography. Ethnic and Racial Studies. 37(10): 1687-1711.

World Bank (2014). In http://www.worldbank.org/en/region/eca/brief/roma (Accessed: 20.10.2015). 


\section{ANNEXES}

Table A1.

Descriptive measures of variables included in the model

\begin{tabular}{|l|c|c|}
\hline & $\%$ & Average \\
\hline Street trading (dummy) & 22.6 & \\
\hline Unemployed (dummy) & 77.3 & \\
\hline Self-employed (dummy) & 23.6 & \\
\hline Social work beneficiary (dummy) & 68.2 & \\
\hline Boys attend school longer than girls & & 3.3 \\
\hline Boys are more important than girls & & 2.2 \\
\hline Women should perform deep mourning & & 3.4 \\
\hline Men should take the major decisions in the family & & 3.6 \\
\hline Women shouldn't argue with husband & & 2.9 \\
\hline Home humidity (dummy) & 55.9 & \\
\hline House is cold (dummy) & 53.2 & \\
\hline Noises at home (dummy) & 57.4 & \\
\hline Employee (dummy) & 15.8 & \\
\hline Social Security contributor (dummy) & 18.4 & \\
\hline Cigano spouse (dummy) & 85.7 & \\
\hline Cigano ancestor (dummy) & 91.7 & \\
\hline Church attendance frequency & & \\
\hline Never & 22.4 & \\
\hline Only on holy days & 7.8 & \\
\hline Once a month & 13.6 & \\
\hline Once a week & & \\
\hline More than once a week & & \\
\hline Every day & & \\
\hline & & \\
\hline
\end{tabular}

Data source: National Study on Ciganos Communities, 2014. Authors' calculations. 
SOCIAL AND SPATIAL CONTINUITIES AND DIFFERENTIATIONS AMONG PORTUGUESE CIGANOS...

Table A2.

Average of factorial scores per geographical unit

\begin{tabular}{|l|c|c|c|c|c|}
\hline & $\mathbf{1}$ & $\mathbf{2}$ & $\mathbf{3}$ & $\mathbf{4}$ & $\mathbf{5}$ \\
\hline Aveiro & -0.55 & 0.09 & -0.22 & -0.37 & -0.11 \\
\hline Beja & -0.16 & 0.71 & 0.15 & 0.37 & 0.30 \\
\hline Braga and Viana do Castelo & 0.13 & -0.07 & 0.00 & -0.14 & -0.31 \\
\hline Bragança and Vila Real & -0.71 & -0.23 & 0.37 & -0.14 & -0.20 \\
\hline Castelo Branco & 0.16 & -0.10 & -0.28 & 0.18 & 0.18 \\
\hline Coimbra & -0.36 & -0.02 & -0.22 & -0.03 & -0.10 \\
\hline Évora & -0.02 & 0.21 & -0.03 & -0.06 & -0.15 \\
\hline Faro & -0.15 & 0.42 & 0.13 & -0.13 & 0.16 \\
\hline Guarda and Viseu & -0.23 & -0.14 & -0.03 & 0.11 & -0.05 \\
\hline Leiria and Santarém & -0.26 & -0.02 & 0.49 & 0.37 & -0.13 \\
\hline Lisbon & 0.65 & -0.39 & 0.19 & -0.09 & 0.06 \\
\hline Portalegre & -0.46 & 0.07 & 0.10 & 0.94 & 0.40 \\
\hline Porto & -0.22 & -0.08 & -0.15 & -0.16 & -0.08 \\
\hline Setúbal & 0.30 & -0.09 & -0.50 & 0.17 & -0.20 \\
\hline
\end{tabular}

Data source: National Study on Ciganos Communities, 2014. Authors' calculations. 
Table A3.

Residence county of the respondents and county aggregation

\begin{tabular}{|c|c|c|c|}
\hline & $\mathbf{n}$ & & $\mathbf{n}$ \\
\hline Aveiro & 144 & Aveiro & 144 \\
\hline Beja & 125 & Beja & 125 \\
\hline Braga & 30 & \multirow[t]{2}{*}{ Braga and Viana do Castelo } & \multirow{2}{*}{41} \\
\hline Viana do Castelo & 11 & & \\
\hline Bragança & 23 & \multirow[t]{2}{*}{ Bragança and Vila Real } & \multirow{2}{*}{41} \\
\hline Vila Real & 18 & & \\
\hline Castelo Branco & 44 & Castelo Branco & 44 \\
\hline Coimbra & 80 & Coimbra & 80 \\
\hline Évora & 80 & Évora & 80 \\
\hline Faro & 166 & Faro & 166 \\
\hline Guarda & 23 & \multirow[t]{2}{*}{ Guarda and Viseu } & \multirow{2}{*}{51} \\
\hline Viseu & 28 & & \\
\hline Leiria & 18 & \multirow[t]{2}{*}{ Leiria and Santarém } & \multirow{2}{*}{83} \\
\hline Santarém & 65 & & \\
\hline Lisbon & 346 & Lisbon & 346 \\
\hline Portalegre & 48 & Portalegre & 48 \\
\hline Porto & 220 & Porto & 220 \\
\hline Setúbal & 130 & Setúbal & 130 \\
\hline Total & 1,599 & Total & 1,599 \\
\hline
\end{tabular}

Data source: National Study on Ciganos Communities, 2014. Authors' calculations. 